\title{
Optical projection tomography imaging to study kidney organogenesis
}

\author{
Renata Prunskaite-Hyyryläinen
}

Faculty of Biochemistry and Molecular Medicine, University of Oulu, Finland. Renata.Prunskaite@oulu.fi

\begin{abstract}
Optical projection tomography (OPT) is a 3D imaging technology. The 3D tomographic reconstruction permits precise analysis and quantification of various structures in developing embryonic tissues, adult organs of small rodents or biopsies. OPT enables detailed and accurate studies of kidney organogenesis, namely ureteric tree branching morphogenesis and nephron quantification.
\end{abstract}

Key words: Optical projection tomography, phenotyping, 3D imaging, branching morphology, nephron quantification, whole mount immunostaining, whole mount in situ hybridization.

\section{Introduction}

Optical projection tomography (OPT) is a three-dimensional (3D) imaging technology. It allows rapid 3D imaging of mesoscopic $(1 \mathrm{~mm}$ to $10 \mathrm{~mm}$ ) specimens that have fluorescent and non-fluorescent signals (1). This technique has made a significant impact in the field of developmental biology. OPT permits acquisition of 3D digital data, which is used for computational analysis of multiple parameters such as developing kidney ureteric tree branch length, angles or nephron distribution and counts.

Prior the OPT scan the specimen is stained and embedded to an agarose gel which serves as a support during imaging. The clearing agents are used to optically clear the specimen. This will enable light passage through the tissue with minimal scattering, absorption and reflection. Cleared specimen is attached to a magnetic holder and steadily rotated 360 degrees around a single axis. A digital image is taken at every chosen angular step (0.45-0.9 degrees). After image acquisition, virtual sections are reconstructed by using a back-projection algorithm. The high-resolution images can be viewed and analyzed as tomographic sections and as a whole.

Here we describe detailed step-by-step protocols for mouse embryonic kidney preparation for OPT after whole mount immunostaining, whole mount in situ hybridization (WISH) or both techniques combined.

Whole mount immunostaining permits antibody staining and protein expression detection in entire embryo or tissue. The WISH is using labeled complimentary RNA to localize specific RNA sequence in the tissue. There are numerous WISH protocols, here we will describe an automated whole mount in situ hybridization procedure (2). Automated process allows completing the WISH within three days with moderate hands on time versus laborious five-day manual protocol. The automated WISH protocol can be done manually using the same material and procedure. It will also be described how to combine WISH and immunostaining techniques allowing simultaneous examination of protein and RNA expression in the same tissue. 


\section{Materials}

\subsection{Whole mount immunostaining}

1. Phosphate Buffered Saline (PBS).

2. PBT-X-100: 1x phosphate buffered saline (PBS) with $0.1 \%$ Triton-X-100 added. Make fresh.

3. Paraformaldehyde (PFA) 4\%: dissolve PFA powder in $1 \times \mathrm{XBS}$, in water bath at $65^{\circ} \mathrm{C}$. Filter through $0.45 \mu \mathrm{m}$ syringe filter.

4. Bleaching buffer: $15 \% \mathrm{H}_{2} \mathrm{O}_{2}$ and $15 \%$ dimethyl sulfoxide (DMSO) dilute in absolute methanol and filter through $0.45 \mu \mathrm{m}$ syringe filter.

5. Blocking solution: $5 \%$ DMSO, $10 \%$ of heat-inactivated serum, derived from the same species as secondary antibody, diluted in PBT-X-100. Filter through $0.45 \mu \mathrm{m}$ syringe filter.

\subsubsection{Whole mount in situ hybridization probe synthesis}

1. RNAase free diethylpyrocarbonate (DEPC) treated water: $1 / 100$ vol $10 \%$ DEPC in $100 \%$ EtOH add double distilled (dd) water and autoclave.

2. 5x transcription optimized buffer (Promega), comes with the RNA polymerase and contains DTT $100 \mathrm{mM}$ (Promega).

3. Dig RNA labeling Mix 10X Conc (Roche).

4. RNAse inhibitor, Recombinant RNasin ${ }^{\circledR}$ Ribonuclease Inhibitor 2500u, Promega.

5. Appropriate RNA polymerase: SP6, T3 or T7.

6. DNAse I (Promega).

7. $4 \mathrm{M} \mathrm{LiCl}$ : dissolve in DEPC water and autoclave.

8. $70 \%$ Ethanol diluted in DEPC water.

\subsubsection{Whole mount in situ hybridization}

1. Diethylpyrocarbonate (DEPC) treated water made as in 2.2.1 item 1.

2. Phosphate Buffered Saline (PBS).

3. PBT-20: 1x PBS with 0.1\% Tween20. Make fresh.

4. Hybridization buffer: 50\% ultra-pure formamide, 5x SSC (20x SSC stock solution: $175 \mathrm{~g} \mathrm{NaCl}$, $88.2 \mathrm{~g} \mathrm{Na}$ citrate, set $\mathrm{pH}$ to 4.5 , add DEPC water up to $1 \mathrm{~L}$.), $50 \mu \mathrm{g} / \mathrm{ml}$ of tRNA, $1 \% \mathrm{SDS}, 50 \mu \mathrm{g} / \mathrm{ml}$ heparin sodium salt Grade I-A and DEPC water. Buffer can be prepared in advance and stored at -20 ${ }^{\circ} \mathrm{C}$ for a month.

5. Proteinase $\mathrm{K}$ stock solution: $10 \mathrm{mg} / \mathrm{ml}$ dissolved in sterile DEPC water, store at $-20{ }^{\circ} \mathrm{C}$. Working solution $0.01 \mathrm{mg} / \mathrm{ml}$ diluted in PBT-20.

6. Paraformaldehyde (PFA) 4\%: dissolve PFA powder in 1x PBS prepared in DEPC treated water, in water bath at $65^{\circ} \mathrm{C}$.

7. Glycine $0.2 \%$ : dissolve in PBT-20, make fresh before use and filter through $0.45 \mu \mathrm{m}$ syringe filter.

8. Hydrogen peroxide 6\%: dilute in DEPC water.

9. Washing buffer I: $25 \mathrm{ml}$ formamide $\geq 99 \% ; 12.520 \mathrm{x} \mathrm{SSC}, \mathrm{pH} 4.5$ (made as in 2.2.2. item 4 but use dd water instead of DEPC), $5 \mathrm{ml} \mathrm{10 \%} \mathrm{SDS,} \mathrm{7,5} \mathrm{ml} \mathrm{dd} \mathrm{water.}$

10. Washing buffer II: $25 \mathrm{ml}$ formamide $\geq 99 \% ; 5 \mathrm{ml} 20 \mathrm{x}$ SSC (made as in 2.2.2. item 4 but use dd water instead of DEPC), $1 \mathrm{ml} 10 \% \mathrm{SDS}, 19 \mathrm{ml}$ DEPC water.

11. Maleic acid buffer (MAB): $100 \mathrm{mM}$ maleic acid, $150 \mathrm{mM} \mathrm{NaCl}, \mathrm{pH} 7.5$.

12. MABT: Maleic acid buffer (MAB) with $0.1 \%$ of Tween 20 . Add Tween20 just before use. 
13. Blocking solution: $0.5 \%$ blocking reagent (Roche) dissolved in MAB according manufacturers recommendations, supplement with $10 \%$ heat inactivated sheep serum.

14. Antibody and antibody dilution buffer: $0.5 \%$ Blocking reagent (same as in item 13, Roche) dissolved in $\mathrm{MAB}$, supplemented with $1 \%$ heat inactivated sheep serum and add anti-DigoxigeninAP Fab (Roche) diluted 1:1000 (1.5 U/ml).

15. NTMT: $100 \mathrm{mM} \mathrm{NaCl}, 100 \mathrm{mM}$ Tris, $\mathrm{pH} 9.5,50 \mathrm{mM} \mathrm{MgCI}_{2}, 1 \%$ Tween20.

16. BM Purple AP Substrate precipitating solution (Roche).

17. InsituPro device from Intavis AG Bioanalytical Instruments or equivalent.

\subsection{Preparation for OPT scanning}

\section{A $5 \mathrm{ml}$ syringe.}

2. Regular or low melting point agar.

3. Clearance solution BABB: Benzyl alcohol and Benzyl benzoate solution dilution ratio 1:2.

4. Clearance solution scaleCUBIC-1 reagent (3): $25 \mathrm{wt} \%$ urea, $25 \mathrm{wt} \%$ N,N,N',N'-tetrakis(2hydroxypropyl) ethylenediamine and $15 \mathrm{wt} \%$ Triton X-100.

5. Super glue (Loctite).

6. Optical Projection Tomography scanner Bioptonics 3001 (Bioptonics) or equivalent.

7. Image reconstruction software nRecon (Skyscan Pty Ltd., Kontich, Belgium).

8. 3D analysis software: open access, Fiji, Drishti, Vaa3D and Kidney Analysis Application (7); commercial, Imaris (Bitplane AG), Amira (Visage Imaging Inc) and Volocity (Perkin Elmer). 


\section{Methods}

\subsection{Whole mount immunostaining}

1. Dissect mouse embryonic kidney or genital ridges, in cold PBS.

2. Fix tissues in ice-cold 4\% PFA for $30 \mathrm{~min}-1 \mathrm{~h}$ depending on mouse age and kidney size (E11.5E13.5- $30 \mathrm{~min}, \mathrm{E} 14.5-\mathrm{E} 16.560 \mathrm{~min})$, at $4{ }^{\circ} \mathrm{C}$.

3. Wash specimens twice for 10 minutes in PBS, to remove PFA.

4. These specimens are ready for whole mount immunostaining (see Note 1 for storing instructions). 5. Bleach specimens in $15 \% \mathrm{H}_{2} \mathrm{O}_{2}$ and $15 \%$ DMSO diluted in absolute methanol at room temperature for $12 \mathrm{~h}$ while rocking.

6. Wash specimen in PBST-X-100 three times for 20 min, while rocking.

7. Block the tissues in blocking solution containing $10 \%$ serum, $5 \%$ DMSO in PBST-X-100 (see Note 2). To ensure good blocking use the serum from the same species where the secondary antibody was derived. Incubate for $12 \mathrm{~h}$ at room temperature, while rocking.

8. Dilute primary antibodies in blocking solution and incubate for $24 \mathrm{~h}$ at room temperature, while rocking.

9. Wash in PBST-X-100 for $12 \mathrm{~h}$, change to fresh PBST-X-100 for six times every $2 \mathrm{~h}$.

10. Dilute secondary antibodies in blocking solution and incubate for $24 \mathrm{~h}$ at room temperature, while rocking.

11. Wash in PBST-X-100 for $12 \mathrm{~h}$, change the solution for five times.

12. Proceed to preparation for OPT scanning (3.4 Preparation for OPT scanning).

\subsection{Whole mount in situ hybridization}

We assume that the gene of interest was already subcloned to the vector (pBlueScript II or other) for in situ probe preparation. The optimal DNA length for RNA probe production is about $800 \mathrm{bp}+/-$ $200 \mathrm{bp}$. It is important to prepare and run simultaneously anti-sense probes for positive signal and sense probes for negative control.

\subsubsection{Probe synthesis}

1. Mix reagents in the following order at room temperature: linearized plasmid $1 \mu \mathrm{g}, 5 \mathrm{x}$ transcription buffer $4 \mu 1$, 10x DIG reaction mix $2 \mu 1,0.1$ M DTT $2 \mu 1$, RNAse inhibitor $1 \mu 1$, polymerase $2 \mu 1$, DEPC water up to total reaction volume $20 \mu 1$.

2. Incubate for $2 \mathrm{~h}$ at $37^{\circ} \mathrm{C}$.

3. Remove one microliter of the mixture and save for electrophoresis gel.

4. Add $2 \mu 1$ DNaseI to the rest of the probe synthesis reaction from the step 1.

5. Incubate for $15 \mathrm{~min}$ at $37^{\circ} \mathrm{C}$.

6. Add $100 \mu \mathrm{DEPC}$ water, $10 \mu \mathrm{l} 4 \mathrm{M} \mathrm{LiCl}, 300 \mu \mathrm{EtOH}$ and mix. Incubate on dry ice or $-70^{\circ} \mathrm{C}$ for $20 \mathrm{~min}$.

7. Spin in the tabletop centrifuge at $4^{\circ} \mathrm{C}$, at $12000 \mathrm{~g}$ for $10 \mathrm{~min}$. Discard the supernatant.

8. Add $200 \mu \mathrm{l}$ of $70 \% \mathrm{EtOH}$ (ethanol diluted with DEPC water), spin in the tabletop centrifuge at $4^{\circ} \mathrm{C}$, at $12000 \mathrm{~g}$ for $10 \mathrm{~min}$. Discard the supernatant.

9. Repeat step 8.

10. Invert the eppendoff tube and air-dry the pellet at room temperature for about $15 \mathrm{~min}$. 
11. Resuspend pellet in $45 \mu 1$ DEPC water. Remove $1 \mu 1$ of solution and save it for electrophoresis gel.

12. Add $45 \mu \mathrm{l}$ formamide to sample, mix well and store at $-70^{\circ} \mathrm{C}$. Probes can be stored at $-70^{\circ} \mathrm{C}$ for several months without any damage.

13. Run electrophoresis gel with the samples from steps 3 and -11. Add $9 \mu 1$ of 1x loading buffer to $1 \mu 1$ of spared specimen and load on the agarose gel. In the specimen from the step 3 will be visible both DNA and RNA bands, whereas in the specimen from the step 11 only RNA band should be visible. If RNA band is visible, proceed to in situ hybridization. If not, repeat and optimize probe synthesis.

\subsubsection{Whole mount in situ hybridization (WISH)}

1. Dissect and fix embryonic kidney as in indicated in 3.1. item 1 and 2. Wash specimens twice in PBS for 10 minutes, $50 \%$ ethanol for $10 \mathrm{~min}$ and twice in $70 \%$ ethanol for $10 \mathrm{~min}$. These specimens are ready for loading to in situ hybridization machine or they can be stored at $-20^{\circ} \mathrm{C}$ for several months (see Note 1).

2. Place specimens to InsituPro machine columns (comes with the device) filled with $70 \%$ ethanol. Use medium incubation columns, with outlet needles. If specimens are very small, use column inserts. Device can process thirty columns at a time and multiple specimens per column (Fig.1). (see note 3 for manual WISH).

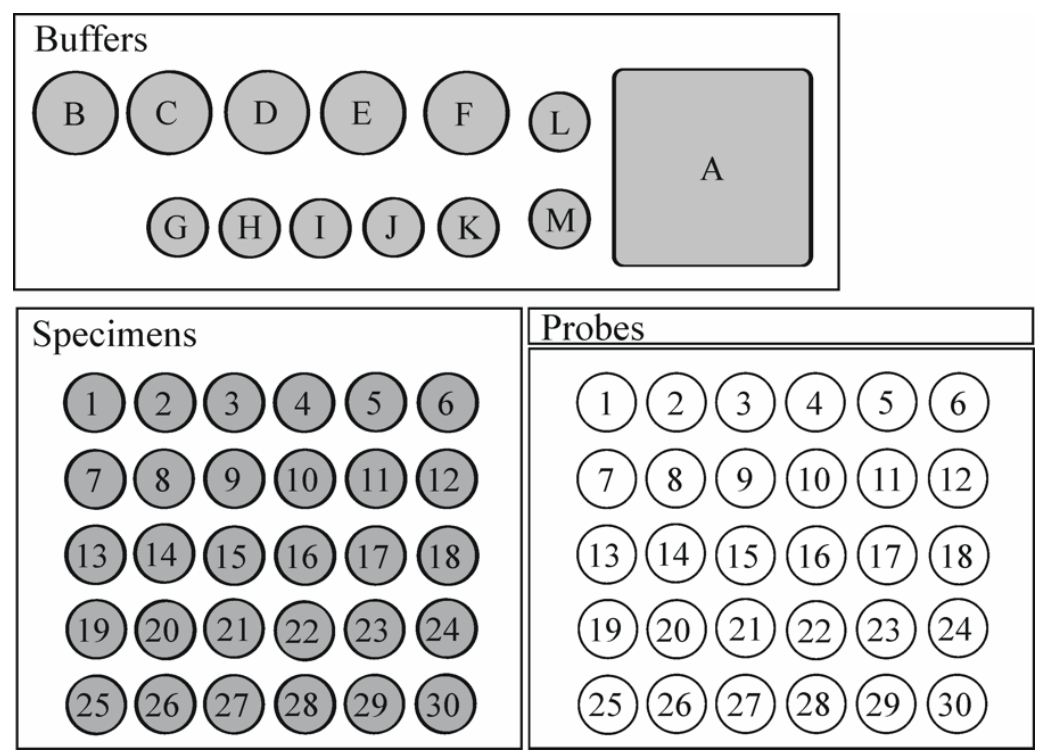

Fig. 1 Schematic representation of buffer, specimen, and probe locations for automated WISH in InsituPro (Intavis AG Bioanalytical Instruments) device.

3. Prepare buffers for Day I (Table 1) and load them to the device in the order indicated in the Fig. 1. 4. Cut the caps of from PCR tubes. Pipette $0.45 \mathrm{ml}$ of prewarmed hybridization buffer, add $2.5 \mu 1$ of RNA probe (about $0.1 \mu \mathrm{g} / \mu \mathrm{l}$ ). The probe concentration might need to be optimized to get best signal. Place tubes with probes in an order corresponding the specimen order (Fig. 1). Robotic arm will pipet 
preheated probe on the specimen during the first day. The hybridization temperature generally ranges from $60-70{ }^{\circ} \mathrm{C}$. It might need to be optimized for each probe individually.

5. Set the program for InsituPro device to run following the manufacturer's instructions. An example for the program is presented in the Table 2 .

6. Based on this program device will stop twice. During the first stop load buffers for Day II and during the second stop load buffers for Day III as in the order indicated in the Table 1.

7. On Day III, once device has stopped, remove specimens from columns and place to a 24 well plate. 8. Add $400 \mu \mathrm{l}$ (or enough to cover the specimen) of BMP purple AP substrate precipitation solution. Wrap to aluminum foil to protect from light. Incubate at room temperature and follow color developing every $30 \mathrm{~min}$. If color dose not develop extend incubation over night at $+4 \mathrm{C}$.

9. As soon as the color is strong and background remains clear, stop reaction by washing in PBT-20 three times for $15 \mathrm{~min}$.

10. Post-fix in $4 \%$ PFA for $1 \mathrm{~h}$ at room temperature.

11. Wash in PBS three times for 10 min.

12. Proceed to preparation for OPT scanning (3.4 Preparation for OPT scanning).

\subsection{Combined whole mount immunostaining and whole mount in situ hybridization}

1. First, follow the whole mount in situ hybridization protocol 3.2.2. after completion wash specimens in PBS twice for $10 \mathrm{~min}$.

2. Proceed with whole mount immunostaining with antibodies of choice as indicated in section 3.1.

3. Once both staining will be completed proceed to preparation for OPT scanning 3.4.

\subsection{Preparation for OPT scanning}

We will refer to Bioptonics 3001 device, there are other open OPT platforms available $(4,5,6)$ and the staining and preparation steps are equally suitable for all.

1. Observe the specimen in bright and fluorescence light under microscope and remove all possible impurities adhered to the surface of the specimen. 
2. Prepare $1 \%$ of regular or low melting point agarose dissolved in purified water and filtered (see Note 4).

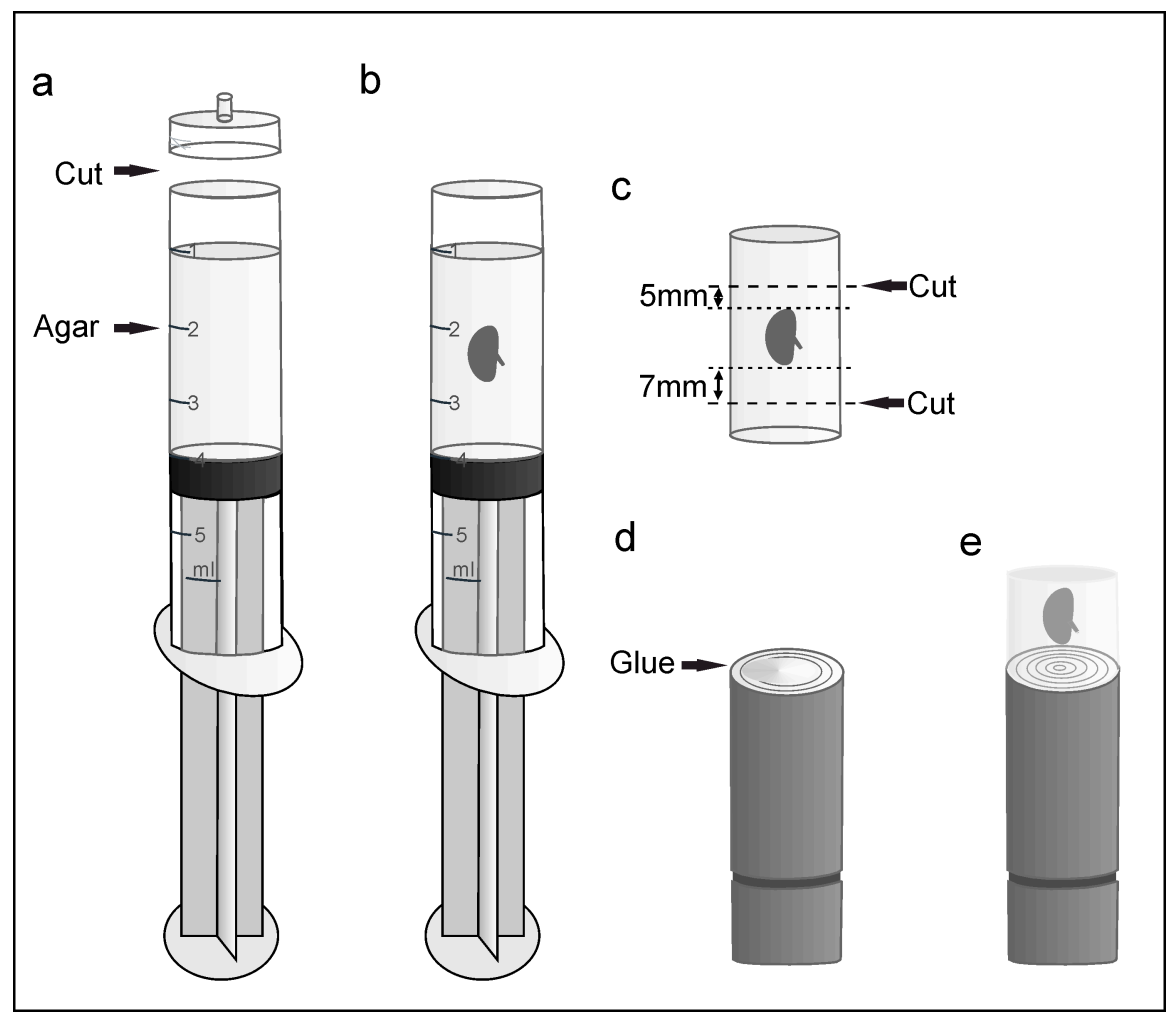

Fig. 2 Tissue embedding to agar and mounting for OPT imaging. Cut the tip of syringe and pour agar (a). Place the specimen in, and move it around to position to the center as gel casts (b). Let the gel set, plunge the gel cylinder out from the syringe, and trim (c). Apply glue to the magnetic holder (d), and place the specimen (e)

3. Cut the tip of $5 \mathrm{ml}$ syringe (Fig. 2a), secure the syringe to stand, put the plunger at $4 \mathrm{ml}$ mark, pour $3 \mathrm{ml}$ of the melted agar in (Fig. 2a) and put in the specimen (Fig. 2b). Keep on swirling specimen around with the plastic sticks or tweezers to position it to the center of the syringe as the gel is solidifying (Fig. 2b). Avoid bubbles. Let it set for $15 \mathrm{~min}$ at $4{ }^{\circ} \mathrm{C}$.

4. Remove gel cylinder from syringe by plunging it out (Fig. 2c).

5. Trim gel cylinder by cutting excess gel. Leave $7 \mathrm{~mm}$ gap between specimen and bottom. This will ensure that there is enough working distance and the magnetic holder will not be visible during imaging. Leave $5 \mathrm{~mm}$ gap between specimen and the top cut (Fig. 2c).

6. Clear the specimen in BABB (3.4. item 7) or ScaleCUBIC-1 (3.4. item 8).

7. Benzyl alcohol: Benzyl benzoate solution (BA:BB, 1:2). Prior BABB clearance dehydrate tissue in $50 \%$ ethanol for $2 \mathrm{~h}$, absolute ethanol $6 \mathrm{~h}$ and fresh absolute ethanol for $6 \mathrm{~h}$. Add BABB and incubate for $12 \mathrm{~h}$. Change to fresh BABB after $12 \mathrm{~h}$ and continue clearance for another $12 \mathrm{~h}$ or as long as specimen will become transparent (See Note 5 and 6).

8. ScaleCUBIC-1 reagent clearance method will take longer time but will not require tissue dehydration. Change ScaleCUBIC-1 reagent after $24 \mathrm{~h}$ and continue clearance until specimen will become transparent (see Note 5). 
9. Once specimen is cleared, remove it from the solution and slightly dry the bottom side on a paper. Apply glue on the magnetic holder (Fig. 2d) and place the specimen on the top (Fig. 2e). Let it set for about $15 \mathrm{~min}$.

10. Prepare OPT device for scanning following the appropriate instructions.

11. Place the prepared specimen into the device and scan it in clearance solution. Choose the correct acquisitions channels: fluorescence or/and transmission. On Bioptonics 3001 device, set camera resolution to high $(1,024 \times 1,024)$, rotation steps to $0.45^{\circ}$ and the zoom to fit specimen to the field of view at all rotational angles. The specimen will rotate $360^{\circ}$ and device will acquire 800 images.

12. Reconstruct scanned images to $z$-series to acquire OPT tomographic data by using nRecon software.

13. Proceed to analysis by your favorite software (software list is in 2.3. item 8).

14. An example of double immuno-labeled mouse kidney at E16.5 with anti-Troma (grey) and antiNephrin (red) antibodies (Fig. 3). The software-assisted quantification of nephrons is rather rapid and accurate (Fig. 4), in this case we have used Spots detection feature available on Imaris software.

15. An example of terminal tip quantification. We have used WISH method and RNR probe (Wnt11, depicted in red) to detect and quantify terminal tips of the developing ureteric tree in E15.5 mouse kidney and quantified them using Spots detection feature available on Imaris software (Fig.5).

16. An example of ureteric tree branching analysis in developing mouse kidney at E15.5 by filament tracing function (Imaris) (Fig. 6). Analysis permits to acquire multiple parameters such as branching angles, number of terminal tips, branch length and oth. Kidney were whole mount immunostained with anti-Troma antibody (grey).

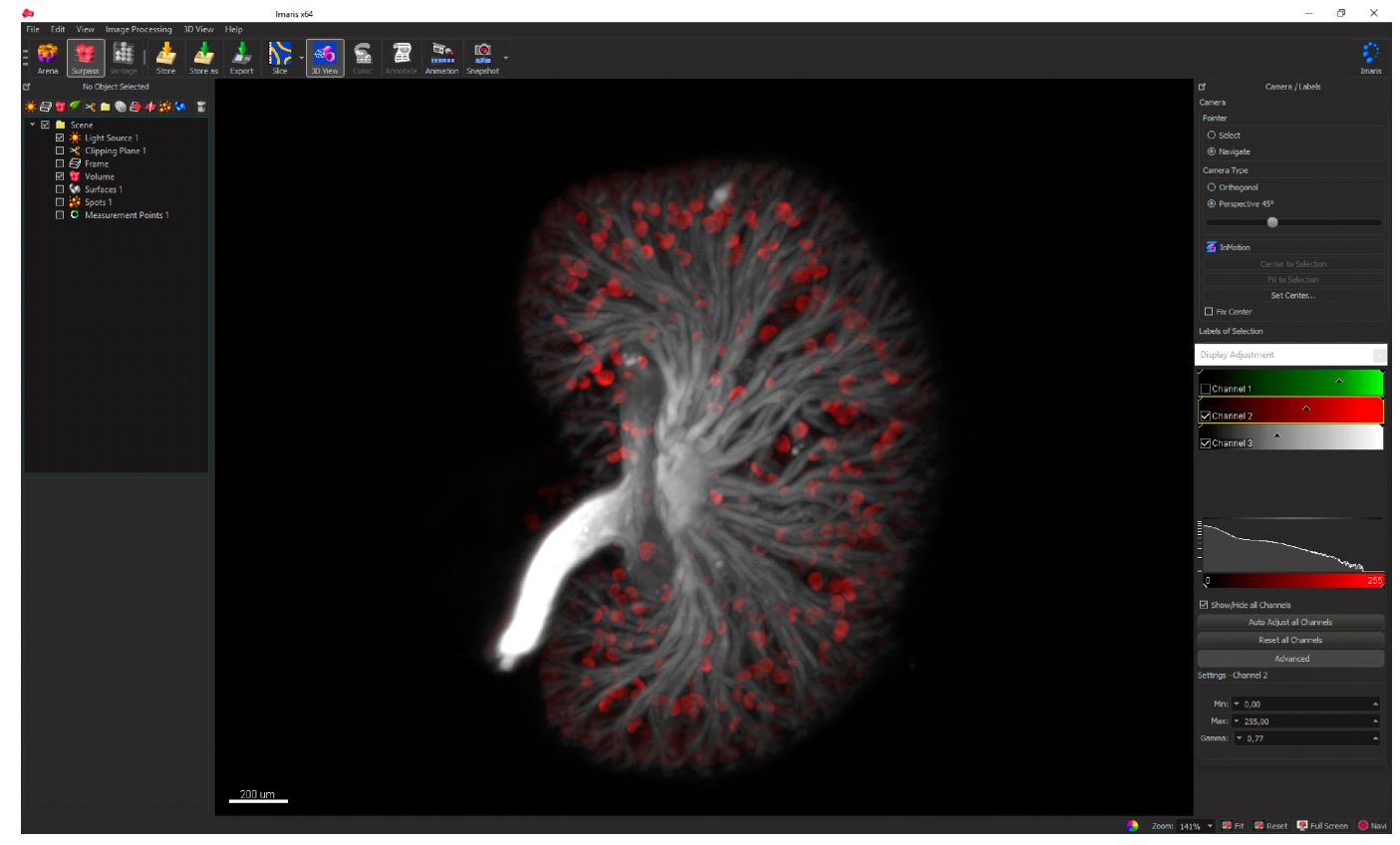

Fig. 3 Representation of E16.5 mouse kidney double immuno-labeled with anti-Troma (gray) depicting ureteric tree and anti-Nephrin (red) antibodies showing nephrons. 3D visualization was done by Imaris program 


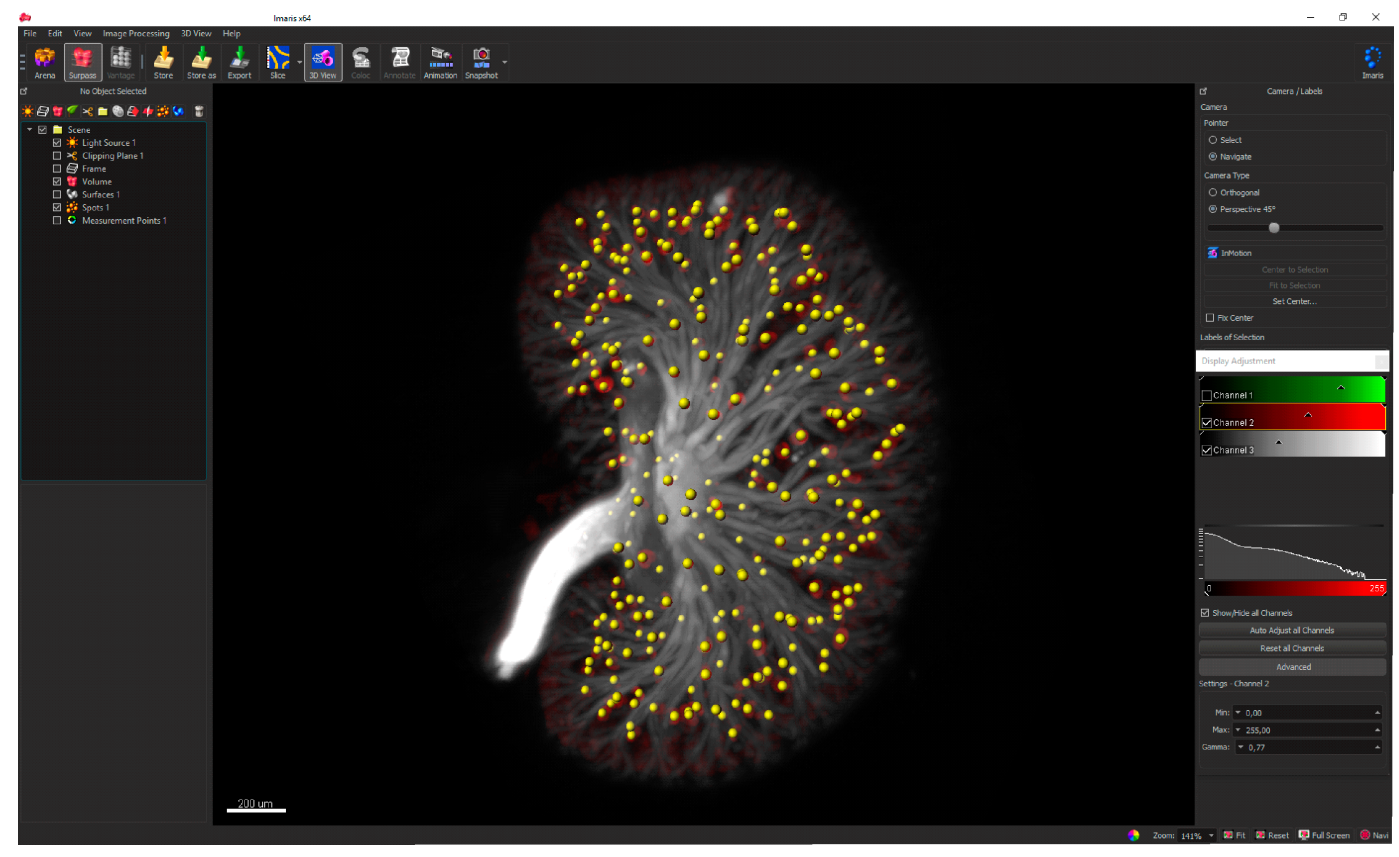

Fig. 4 Example of automated nephron quantification by spot detection function (Imaris). Nephrons are depicted in yellow following nephrin staining (red)

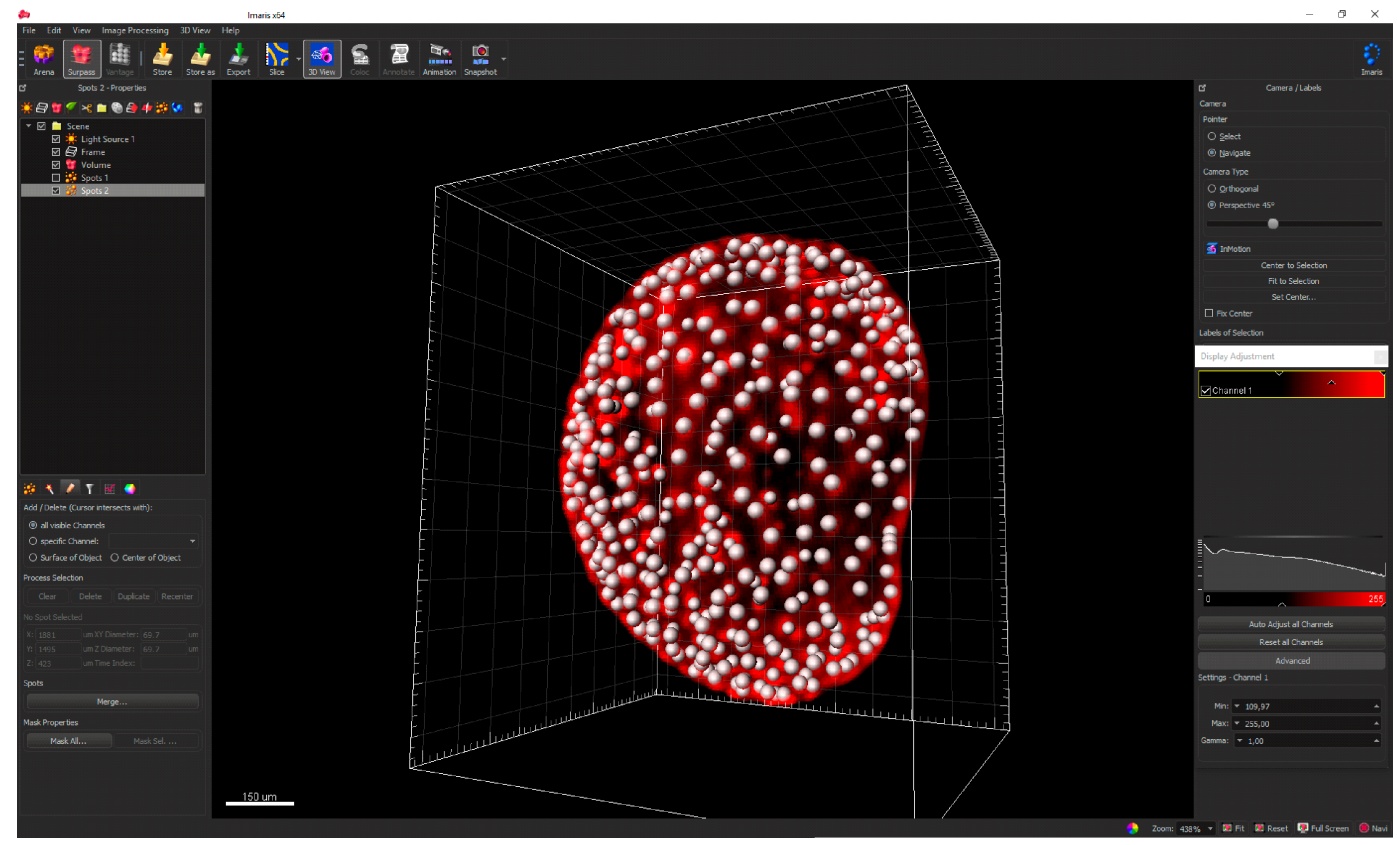

Fig. 5 Ureteric bud (UB) tip quantification by spot detection function (Imaris). UB tips labeled with Wnt11 probe (red) by WISH in mouse kidney at E15.5 


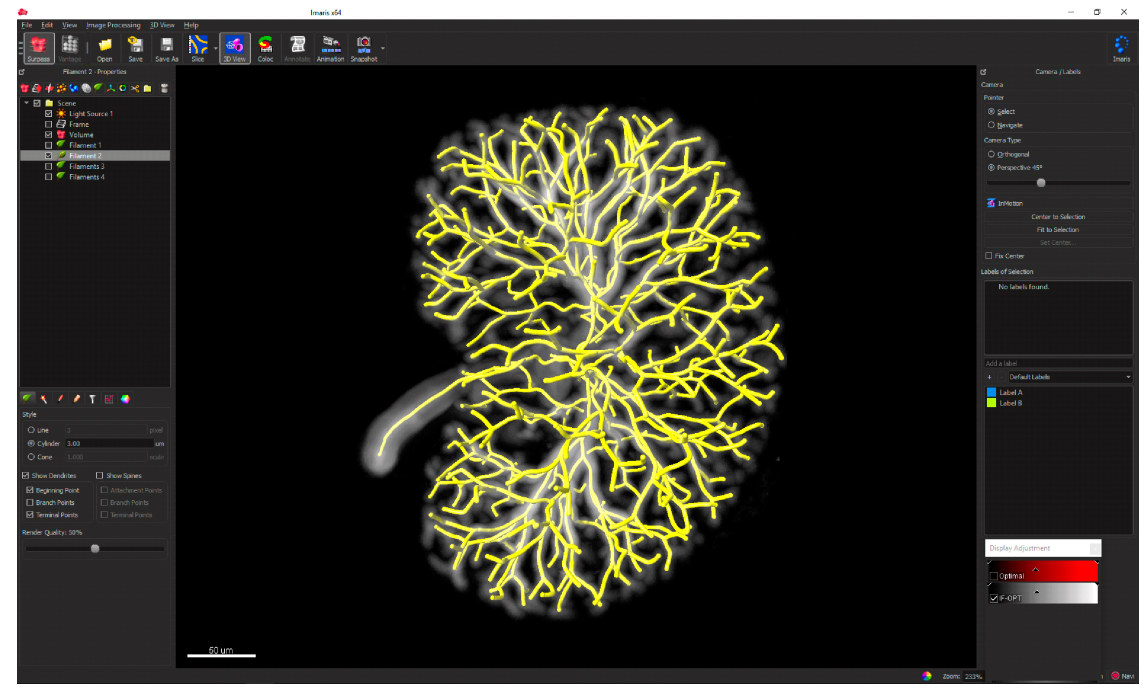

Fig. 6 Ureteric tree analysis in developing mouse kidney at E15.5 by filament tracing function (Imaris). Kidney stained with anti-Troma antibody (gray)

\section{Notes}

1. For storing, dehydrate specimens in 50\% ethanol once for $10 \mathrm{~min}$ and twice in $70 \%$ ethanol for 10 min. Tissues can be stored in $70 \%$ ethanol at $-20{ }^{\circ} \mathrm{C}$ for several months. If specimens were stored in $-70 \%$ ethanol Rehydrate them via ethanol series $(70 \%, 50 \%$ and $30 \%)$ to PBS before starting immunostaining.

2. In order to prevent bacteria growth during long incubation time, supplement buffers with $0.01 \%$ sodium azide.

3. The same protocol can be used to do WISH manually. Place specimens to 24 well plates for washing steps and move them to glass bottles or $2 \mathrm{ml}$ eppendorff tubes for per-hybridization, hybridization and post-hybridization. Prepare all buffers as indicated and follow the procedure and incubation times indicated in the Table 2.

4. Use low melting point agarose (LMP) in cases when it is planned to reuse specimen after scanning for other applications. Other vice, regular agarose can be used. In order to remove specimen form LMP agarose rehydrate it from BABB to absolute ethanol for $6 \mathrm{~h}$, change to fresh ethanol for $6 \mathrm{~h}$, place to $50 \%$ ethanol for $6 \mathrm{~h}$ and PBS for $6 \mathrm{~h}$. Put agarose block in PBS and warm up in water bath at $60{ }^{\circ} \mathrm{C}$. Once gel softens, gently retrieve the specimen.

5. The BABB clearance is rather rapid and suits very well for immunostained specimens. In case of whole mount in situ hybridization, BABB will gradually quench the color. The color will remain intact for about a week in BABB. In case of ScaleCUBIC-1 quenching is not an issue, but clearance will take longer time.

6. When working with BABB solution use appropriate protection, and handle solution in the fume hood. Use glassware as BABB is toxic and melts plastic.

\section{References}

1. Sharpe J., Ahlgren U, Perry P et al (2002) Optical projection tomography as a tool for 3D microscopy and gene expression studies. Science 296: 541-545.

2. Wilkinson D (1998). In Situ Hybridization: A Practical Approach (Practical Approach Series). 
3. Susaki E, Tainaka K, Perrin D et al (2014) Whole-brain imaging with single-cell resolution using chemical cocktails and computational analysis. Cell 157: 726-739.

4. Watson T, Andrews N, Davis S et al (2017) OPTiM: Optical projection tomography integrated microscope using open-source hardware and software. PLoS One 12: e0180309.

5. Wong M, Dazai J, Walls J et al (2013) Design and implementation of a custom built optical projection tomography system. PLoS One 8: e73491.

6. Gualda E, Vale T, Almada P et al (2013) OpenSpinMicroscopy: an open-source integrated microscopy platform. Nat. Methods 10, 599-600.

7. Short K, Hodson M, Smyth I (2010) Tomographic quantification of branching morphogenesis and renal development. Kidney Int. 77, 1132-1139. 
Table 1. The day-by-day work flow, buffer locations and amounts for automated WISH adopted for InsituPro.

\begin{tabular}{|l|l|l|l|l|}
\hline \multirow{2}{*}{ Position } & \multicolumn{3}{|c|}{ Buffers } & $\begin{array}{c}\text { Buffer amount } \\
\text { for 30 samples }\end{array}$ \\
\hline & Day I & Day II & Day III & $100 \mathrm{ml} / 120 \mathrm{ml}$ \\
\hline A & PBT-20 & MABT & & $25 \mathrm{ml}$ \\
\hline B & EtOH 50\% & & & $25 \mathrm{ml}$ \\
\hline C & Hybridization buffer & & $35 \mathrm{ml}$ \\
\hline D & & Washing buffer I & & $35 \mathrm{ml}$ \\
\hline E & & Washing buffer II & & $35 \mathrm{ml}$ \\
\hline F & & MABT & & $12 \mathrm{ml}$ \\
\hline G & Proteinase K & & & $12 \mathrm{ml}$ \\
\hline H & $4 \%$ PFA & & & $12 \mathrm{ml}$ \\
\hline I & Glycine & & & $12 \mathrm{ml}$ \\
\hline J & $6 \%$ H2O2 & & NTMT & $12 \mathrm{ml}$ \\
\hline K & & & & $12 \mathrm{ml}$ \\
\hline L & & Blocking solution & & $12 \mathrm{ml}$ \\
\hline M & & Anti-Dig antibody & & \\
\hline
\end{tabular}


Table 2. Detailed program description for automated WISH adopted for InsituPro (Intavis AG

Bioanalytical Instruments) device.

\begin{tabular}{|c|c|c|c|c|c|}
\hline Nr. & Device action & $\begin{array}{l}\text { Volume/ } \\
\text { specimen }\end{array}$ & Time & Position/Buffer & Comments \\
\hline 1 & $\begin{array}{l}\text { Set temperature } \\
\text { regulation }\end{array}$ & $\mathrm{OFF}$ & & & \\
\hline 2 & Rinse & $5000 \mu l$ & & & System wash \\
\hline 3 & Aliquot & $200 \mu \mathrm{l}$ & & B / Ethanol & Rehydration \\
\hline 4 & Wait & & $5 \mathrm{~min}$ & & \\
\hline 5 & Incubate & $350 \mu \mathrm{l}$ & $5 \mathrm{~min}$ & B / Ethanol & Rehydration \\
\hline 6 & Incubate & $200 \mu \mathrm{l}$ & $0 \min$ & & \\
\hline 7 & Aliquot & $200 \mu 1$ & & A / PBT-20 & Rehydration \\
\hline 8 & Wait & & $5 \mathrm{~min}$ & & \\
\hline 9 & Incubate & $350 \mu 1$ & $15 \mathrm{~min}$ & A / PBT-20 & PBT-20 washes \\
\hline 10 & Incubate & $350 \mu \mathrm{l}$ & $15 \mathrm{~min}$ & A / PBT-20 & PBT-20 washes \\
\hline 11 & Incubate & $350 \mu \mathrm{l}$ & $1 \mathrm{~h}$ & $\mathrm{~J} / 6 \% \mathrm{H} 2 \mathrm{O} 2$ & Bleaching \\
\hline 12 & Incubate & $350 \mu \mathrm{l}$ & $15 \mathrm{~min}$ & A / PBT-20 & PBT-20 washes \\
\hline 13 & Incubate & $350 \mu \mathrm{l}$ & $15 \mathrm{~min}$ & A / PBT-20 & PBT-20 washes \\
\hline 14 & Incubate & $350 \mu \mathrm{l}$ & $15 \mathrm{~min}$ & A / PBT-20 & PBT-20 washes \\
\hline 15 & Incubate & $350 \mu 1$ & $35 \mathrm{~min}$ & G / ProtK & Tissue permeabilization \\
\hline 16 & Incubate & $350 \mu \mathrm{l}$ & $5 \mathrm{~min}$ & I / Glycine & Proteinase $\mathrm{K}$ inactivation \\
\hline 17 & Incubate & $350 \mu 1$ & $1 \mathrm{~min}$ & A / PBT-20 & PBT-20 washes \\
\hline 18 & Incubate & $350 \mu \mathrm{l}$ & $35 \mathrm{~min}$ & $\mathrm{H} / 4 \%$ PFA & Post fixation \\
\hline 19 & Incubate & $350 \mu 1$ & $15 \mathrm{~min}$ & A / PBT-20 & PBT-20 washes \\
\hline 20 & Incubate & $350 \mu \mathrm{l}$ & $15 \mathrm{~min}$ & A / PBT-20 & PBT-20 washes \\
\hline 21 & Incubate & $350 \mu 1$ & $15 \mathrm{~min}$ & $\begin{array}{ll}\mathrm{C} / & \text { Hybridization } \\
\text { buffer } & \\
\end{array}$ & Wash \\
\hline 22 & $\begin{array}{l}\text { Set temperature } \\
\text { regulation }\end{array}$ & T2 (HIGH) & & & $\begin{array}{l}\text { Set hybridization temperature } \\
(60-70 \mathrm{C})\end{array}$ \\
\hline 23 & Incubate & $350 \mu \mathrm{l}$ & $1 \mathrm{~h}$ & $\begin{array}{ll}\mathrm{C} / & \text { Hybridization } \\
\text { buffer } & \\
\end{array}$ & Pre-hybridization \\
\hline 24 & Incubate & $350 \mu 1$ & $15 \mathrm{~h}$ & Probes & $\begin{array}{l}\text { Hybridisation: robe will be } \\
\text { pipetted on specimen }\end{array}$ \\
\hline 25 & Wait for Key & $350 \mu l$ & & & $\begin{array}{l}\text { Device will stop; Load Day II } \\
\text { buffers and continue }\end{array}$ \\
\hline 26 & Incubate & $350 \mu \mathrm{l}$ & $30 \mathrm{~min}$ & D / Washing buffer I & Post-hybridization washes I \\
\hline 27 & Incubate & $350 \mu 1$ & $30 \mathrm{~min}$ & D / Washing buffer I & Post-hybridization washes I \\
\hline 28 & Incubate & $350 \mu \mathrm{l}$ & $30 \mathrm{~min}$ & D / Washing buffer I & Post-hybridization washes I \\
\hline 29 & Incubate & $350 \mu 1$ & $30 \mathrm{~min}$ & E / Washing buffer II & Post-hybridization washes II \\
\hline 30 & Incubate & $350 \mu \mathrm{l}$ & $30 \mathrm{~min}$ & E / Washing buffer II & Post-hybridization washes II \\
\hline 31 & Incubate & $350 \mu \mathrm{l}$ & $30 \mathrm{~min}$ & E / Washing buffer II & Post-hybridization washes II \\
\hline 32 & $\begin{array}{l}\text { Set temperature } \\
\text { regulation }\end{array}$ & OFF & & & \\
\hline 33 & Wait & & $15 \mathrm{~min}$ & & \\
\hline 34 & Incubate & $350 \mu \mathrm{l}$ & $15 \mathrm{~min}$ & $\mathrm{~F} / \mathrm{MABT}$ & MABT washes \\
\hline 35 & Incubate & $350 \mu \mathrm{l}$ & $15 \mathrm{~min}$ & $\mathrm{~F} / \mathrm{MABT}$ & MABT washes \\
\hline 36 & Incubate & $350 \mu 1$ & $15 \mathrm{~min}$ & $\mathrm{~F} / \mathrm{MABT}$ & MABT washes \\
\hline 37 & Incubate & $350 \mu \mathrm{l}$ & $15 \mathrm{~min}$ & $\mathrm{~A} / \mathrm{MBT}$ & MABT washes \\
\hline 38 & Incubate & $350 \mu \mathrm{l}$ & $1 \mathrm{~h}$ & L / Blocking solution & Blocking \\
\hline 39 & Incubate & $350 \mu \mathrm{l}$ & $6 \mathrm{~h}$ & M / Antibody & anti-Dig antibody staining \\
\hline 40 & Incubate & $350 \mu 1$ & $15 \mathrm{~min}$ & $\mathrm{~A} / \mathrm{MBT}$ & MABT washes \\
\hline 41 & Incubate & $350 \mu \mathrm{l}$ & $15 \mathrm{~min}$ & $\mathrm{~A} / \mathrm{MBT}$ & MABT washes \\
\hline 42 & Incubate & $350 \mu 1$ & $15 \mathrm{~min}$ & $\mathrm{~A} / \mathrm{MBT}$ & MABT washes \\
\hline 43 & Incubate & $350 \mu 1$ & $20 \mathrm{~min}$ & $\mathrm{~A} / \mathrm{MBT}$ & MABT washes \\
\hline 44 & Incubate & $350 \mu \mathrm{l}$ & $20 \mathrm{~min}$ & $\mathrm{~A} / \mathrm{MBT}$ & MABT washes \\
\hline 45 & Incubate & $350 \mu 1$ & $20 \mathrm{~min}$ & $\mathrm{~A} / \mathrm{MBT}$ & MABT washes \\
\hline
\end{tabular}




\begin{tabular}{|l|l|l|l|l|l|}
\hline 46 & Incubate & $350 \mu \mathrm{l}$ & $40 \mathrm{~min}$ & A / MBT & MABT washes \\
\hline 47 & Incubate & $350 \mu \mathrm{l}$ & $40 \mathrm{~min}$ & A / MBT & MABT washes \\
\hline 48 & Incubate & $350 \mu \mathrm{l}$ & $40 \mathrm{~min}$ & A / MBT & MABT washes \\
\hline 49 & Incubate & $350 \mu \mathrm{l}$ & $50 \mathrm{~min}$ & A / MBT & MABT washes \\
50 & Wait for Key & & & & $\begin{array}{l}\text { Device will stop; Load Day III } \\
\text { buffers and continue }\end{array}$ \\
\hline 51 & Incubate & $350 \mu \mathrm{l}$ & $15 \mathrm{~min}$ & $\mathrm{~K} /$ NTMT & NTMT washes \\
\hline 52 & Rinse temperature & $350 \mu \mathrm{l}$ & $\begin{array}{l}5000 \\
\mu \mathrm{l}\end{array}$ & & \\
\hline 53 & $\begin{array}{l}\text { Set } \\
\text { regulation }\end{array}$ & $350 \mu \mathrm{l}$ & OFF & & End of program \\
\hline
\end{tabular}




\section{Figure legends}

Fig. 1. Schematic representation of buffer, specimen and probe locations for automated WISH in InsituPro (Intavis AG Bioanalytical Instruments) device.

Fig. 2. Tissue embedding to agar and mounting for OPT imaging. Cut the tip of syringe and pour agar (a). Place the specimen in, move it around to position to the center as gel casts (b). Let gel set, plunge the gel cylinder out from the syringe and trim (c). Apply glue to the magnetic holder (d) and place the specimen (e).

Fig. 3. Representation of E16.5 mouse kidney double immuno-labeled with anti-Troma (grey) depicting ureteric tree and anti-Nephrin (red) antibodies showing nephrons. 3D visualization was done by Imaris program.

Fig. 4. Example of automated nephron quantification by Spot detection function (Imaris). Nephrons are depicted in yellow following Nephrin staining (red).

Fig. 5. Ureteric bud (UB) tip quantification by spot detection function (Imaris). UB tips labeled with Wnt11 probe (red) by WISH in mouse kidney at E15.5

Fig. 6. Ureteric tree analysis in developing mouse kidney at E15.5 by filament tracing function (Imaris). Kidney stained with anti-Troma antibody (grey). 